\title{
Navorsings- en oorsigartikels
}

\section{Die toepassing van peptiedblootlegging op fage in trombose en hemostase}

\author{
S.M. Meiring ${ }^{*}$, H.F. Kotzé, G.H.J. Pretorius en P.N. Badenhorst \\ Departement Hematologie en Selbiologie, Universiteit van die Oranje-Vrystaat, Posbus 339(G2), Bloemfontein, 9300 \\ *Outeur aan wie korrespondensie gerig kan word.
}

Ontvang 6 Julie 1999; aanvaar 31 Augustus 1999

UITTREKSEL

Die omvang en gebruike van die tegnologie van peptiedblootlegging op fage, en die toepassing daarvan op die gebied van trombose en hemostase en van geneesmiddelontwerp word bespreek. Die algemene beginsels van die tegniek word verduidelik.

\begin{abstract}
The application of phage display technology in thrombosis and haemostasis

The scope and utility of phage display are reviewed with emphasis on application in the field of ihrombosis and haemostasis and drug design. General principles of this technique are described.
\end{abstract}

\section{INLEIDING}

Hemostase is 'n beskermende meganisme wat oormatige bloedverlies beperk wanneer bloedvate beskadig word en help om 'n fisiologiese homeostase te handhaaf. Normale hemostase word bewerkstellig deur 'n reeks komplekse interaksies tussen bloedvate, bloedselle, stollingsfaktore en -inhibeerders, asook die fibrinolitiese stelsel. Trombose, aan die anderkant, word allerweë as die teenbeeld van hemostase beskou. Na beskadiging van die bloedvat-endoteel, sodra die bloed in aanraking met die subendoteel kom, kleef die bloedplaatjies m.b.v. die glikoproteien (GP) Ib/IX/V-reseptore op hulle membrane aan die subendoteel en word geaktiveer. Geaktiveerde plaatjies stel die reseptor GP IIb/IIIa op hulle oppervlak bloot, waaraan die klewingsproteïene, veral fibrinogeen en von Willebrandfaktor ( $\vee W F$ ) bind. Die klewingsproteïene bevat 'n Arg-Gly-Aspvolgorde wat aan GP IIb/IIIa bind. Terselfdertyd word stollingsfaktore geaktiveer om trombien te vorm en word die plaatjieprop versterk om oormatige bloedverlies te verhoed. ${ }^{\text {I Endoteelselle in }}$ die omgewing van die beskadigde wand skei tromboreguleerders (prostasiklien, stikstofoksied en fibrinolitiese middels) af, wat die grootte van die prop beperk. ${ }^{2}$ Die plasminogeenaktiveerders, $\mathrm{nl}$. weefseltipe plasminogeenaktiveerder (tPA) en urokinase-tipe plasminogeenaktiveerder (UPA) is belangrike fibrinolitiese middels wat die pro-ensiem plasminogeen aktiveer om plasmien te vorm. Plasmien verteer die onoplosbare fibrien in die plaatjieprop na oplosbare afbraakprodukte en sodoende beperk dit die grootte van die prop. Plasminogeenaktiveerderinhibeerders (PAI) is proteiene wat tPA en uPA inhibeer. Oormatige aktivering van plaatjies deur biomateriale en aterosklerotiese letsels, oorkom egter hierdie tromboregulerende meganismes. Wanneer dit gebeur, verander die plaatjies en stollingsfaktore in trombotiese oortreders wat trombo-embolieë veroorsaak en bloedvate kan afsluit. Dit lei tot potensieel fatale siektes, soos akute miokardiale infarksie en beroerte. ${ }^{3}$ Die belang van trombo-emboliese komplikasies van arteriële bloedvatsiektes word al hoe meer besef en dit het gelei tot die soektog na meer effektiewe antitrombotiese middels.
Die tegnologie van peptied- of proteïenblootlegging op fage is 'n kragtige en vinnige tegniek om proteïene met spesifieke antitrombotiese funksies te isoleer en/of te ontwerp en word reeds aangewend in die ontwikkeling van nuwe antitrombotiese middels. Dit is egter nodig om die tegniek van peptiedblootlegging op fage te verduidelik voordat die toepassing daarvan in trombose en hemostase bespreek word.

\section{PEPTIEDBLOOTLEGGING OP FAGE}

Peptiedblootlegging op fage is 'n tegniek waar 'n peptied of proteïen op die oppervlak van ' $n$ filamenteuse faag blootgelê word. Dit word gedoen deur 'n gekose geen of geenfragment wat vir 'n oppervlakproteïen kodeer in die faaggeen in te bou. Hierdie inbouing beînvloed nie die noodsaaklike funksies van die oppervlakproteïene nie en lei tot die blootlegging van 'n fusiepeptied of -proteïen op die oppervlak van die faag. Die peptied of proteïen kan dan as ' $n$ ligand, ensiem, immunogeen of enige ander aktiewe deelnemer in 'n biologiese reaksie optree. Hierdie tegniek is eerste deur Smith in $1985^{4}$ gebruik. Hy het 'n versameling of biblioteek van lukraakgekose peptiedvolgordes aan die amino-terminus van die mantelproteïen, glikoproteïen (GP) III, op die oppervlak van 'n faag M13 blootgelê. Wanneer lukraakgekose DNA-volgordes in faaggenome ingebou word, word lukraak peptiede op die oppervlak van die fage blootgelê en dit lei tot 'n groot mengsel van faagklone wat elk 'n verskillende peptiedvolgorde op die oppervlak blootlê. Uit hierdie mengsel van faagklone (faagbiblioteek) word fage wat aan 'n teikenproteien bind, geselekteer. Die geselekteerde fage kan dan in bakterieë soos $E$. coli vermeerder word. Die aminosuurvolgorde van die peptiede op die geselekteerde fage word afgelei deur die ingevoegde DNA se volgorde m.b.v. bestaande tegnieke te bepaal. Die krag van hierdie tegniek lê daarin dat funksionele aktiwiteit gekoppel kan word aan genetiese inligting. Peptiedblootlegging bring vinnige seleksie van 'n gekose proteïen mee, terwyl die genetiese inligting vinnige en betroubare vermeerdering van fage meebring. Dit lei tot die produksie van groot hoeveelhede moontlike interessante teikens. Die tegnologie word ook gebruik om antiliggaam-epitope suksesvol te bepaal. $\mathrm{om}$ 
struktuurfunksie-verwantskappe van sellulêre reseptore te bestudeer en om ensiemsubstraat-spesifisiteit na te vors en te verander. Om die tegniek beter te verduidelik, word elke faset daarvan in meer besonderhede bespreek.

\section{Filamenteuse faag}

Filamenteuse fage is ideaal geskik vir in vitro-seleksie omdat hulle klein genome bevat waarin groot biblioteke van 'n verskeidenheid verskillende gene maklik ingebou kan word. Die enkelstring-DNA-fage ( $\mathrm{fd}$ of $\mathrm{M} 13$ ) word meestal gebruik. Hierdie fage het 'n deursnee van $6 \mathrm{~nm}$ en is $1000-2000 \mathrm{~nm}$ lank. Aan die een punt is daar 5 kopieë van elk van die mantelproteïene GP III en VI (figuur 1). Die hoof-mantelproteïen, GP VIII, kom in 2800 kopieë op die sye van die faag voor. Beide GP III en VIII stel hulle aminoterminale op die oppervlak van die faag bloot, terwy! GP VI se karboksielkant ekstrasellulêr geleë is. Die faaggenoom bevat sowat 6500 nukleotiede.

Die lewensiklus van $\mathrm{fd}$ en M13 filamenteuse fage begin wanneer hulle $E$. coli infekteer. Die faag bind aan die punt van die Ftipe geslagspilus van die $E$. coli en word in die sel ingeneem. Die F-pilus van die $E$. coli breek dan af sodat 'n $E$. coli slegs deur een faag met 'n spesifieke DNA-samestelling geïnfekteer kan word. Die gevolg is die ontstaan van 'n bakteriële kolonie, wat fage met dieselfde peptiedvolgorde produseer. $\mathrm{Na}$ inname word die enkelstring faag-DNA na 'n dubbelstring-vorm omgeskakel. Daarna volg herhaaldelike replisering, transkripsie van faaggene, proteïensintese en uiteindelike vrystelling as fage. Die meganismes wat hierdie prosesse reguleer, is goed bekend maar buite die bestek van hierdie oorsig. ${ }^{5}$ Dit is belangrik om daarop te let dat die faag nie die gasheer doodmaak nie, en dat 'n $E$. coli wat deur een faag geïnfekteer is, tussen 100 en I 000 nuwe fage tydens een generasietydperk produseer.

\section{Konstruksie van 'n faagbiblioteek}

'n Faagbiblioteek word gebou deur 'n versameling vreemde oligonukleotiede in die M13- of fd-faaggenome in te bou. ' $n$ Tetrasiklien- (of enige ander antibiotikum) weerstandsgeen en restriksie-ensiemsnypunte word eerstens in die faaggenoom ingebou. Die tetrasiklien-weerstandsgeen bring mee dat geînfekteerde $E$. coli weerstandbiedend is teen tetrasiklien. Vervolgens word 'n stukkie vreemde DNA, wat as 'n vulsel dien, op so 'n wyse m.b.v. restriksie-ensieme in een van die mantelproteiengene (bv. GP III) ingebou dat die leesraam verskuif. Fage wat hierdie DNA-vulsel bevat, sal 'n mutant van GPIII produseer wat verhoed dat die fage $E$. coli kan infekteer. Hierdie vulsel-DNA word dan verwyder en die gaping word met genoegsame oligonukleotiede gevul sodat die leesraam weer herstel word om 'n funksionele GP III te produseer. So byvoorbeeld sal daar vir 'n heksapeptiedbiblioteek, oligonukleotiede ingebou word wat 'n lukrak volgorde (NNK) ${ }_{0}$ bevat. In hierdie geval beteken dit dat $\mathrm{N}$ gelyke hoeveelhede van al vier nukleotiede adenien, guanien, sitosien en timien bevat, terwyl $\mathrm{K}$ gelyke hoeveelhede guanien en timien bevat. Deur dit so te doen, word die aantal verskillende trinukleotiede wat gevorm word, verminder van $4 \times 4 \times 4=64$ na $4 \times 4 \times 2=32$, terwyl geen stopkodons gevorm word nie. Hierdie geneties gemanipuleerde faagvektore word dan gebruik om $E$. coli te infekteer. Die selle produseer fage wat geïsoleer en gesuiwer kan word, en die biblioteek is gereed vir seleksie. Die totale aantal verskillende heksapeptiede wat uit die 20 aminosure gevorm kan word, is $20^{\circ}=64 \times 10^{\circ}$ fage. 'n Praktiese biblioteek bevat sowat $10^{9}$ tot $10^{14}$ fage wat ongeveer $70 \%$ van alle moontlike aminosuur-volgordekombinasies verteenwoordig.

\section{Seleksie en vermeerdering}

Seleksie van fage word gedoen deur eerstens 'n teikenproteïen (reseptor, antiliggaam, ligand ens.) aan 'n plastiese immuunbuis of aan magnetiese korrels wat vooraf met kitsmelkpoeier of beesserum-albumien (BSA) bedek is, te immobiliseer (figuur 2). Die kitsmelkpoeier of BSA dien as 'n blokkeermiddel om die bindingsetels wat nie deur die teikenproteïen beset word nie, te beset. Die teikenproteïen word vervolgens met die faagbiblioteek geïnkubeer. $\mathrm{Na}$ interaksie word die nie-bindende fage afgewas sodat net fage met peptiede wat aan die teikenproteïen bind, behoue bly. Die bindende fage kan dan nie-spesifiek met 'n sterk suur geëlueer word. Na suur-eluering word die faagoplossing met 'n sterk basis geneutraliseer. Geselekteerde fage kan ook spesifiek geëlueer word. So byvoorbeeld kan antiliggaamgebonde fage met die natuurlike antigeen geëlueer word en reseptorgebonde fage met die ligand. ' $n$ Voorbeeld hiervan is die isolasie van ' $n$ inhibeerder van die trombienreseptor op plaatjies. In hierdie geval word 'n faagbiblioteek met intakte bloedplaatjies geïnkubeer en die bindende fage met die reseptorligand geëlueer Dit dui daarop dat spesifieke kennis oor die reseptor nie nodig is om binders, of met 'n bietjie geluk, inhibeerders te selekteer nie. ${ }^{\circ}$

Die bindende fage word dan oornag met F-pilus-bevattende $E$. coli in hulle eksponensiële groeifase geinkubeer in die teenwoordigheid van 'n antibiotikum (bv. tetrasiklien). Die geïnfekteerde $E$. coli produseer fage wat versamel word deur die $E$. coli-kultuur te sentrifugeer en te suiwer deur 'n aantal poliëtileenglikolnatriumchloried (PEG- $\mathrm{NaCl}$ ) presipiterings- en hersuspenderingsiklusse. Hierdie geselekteerde fage word dan gebruik vir 'n tweede, derde of selfs vierde rondte van seleksie en vermeerdering. Die aantal bindende fage kan op dié wyse met tussen 1000 en 100000 keer per rondte vermeerder word. Die sukses

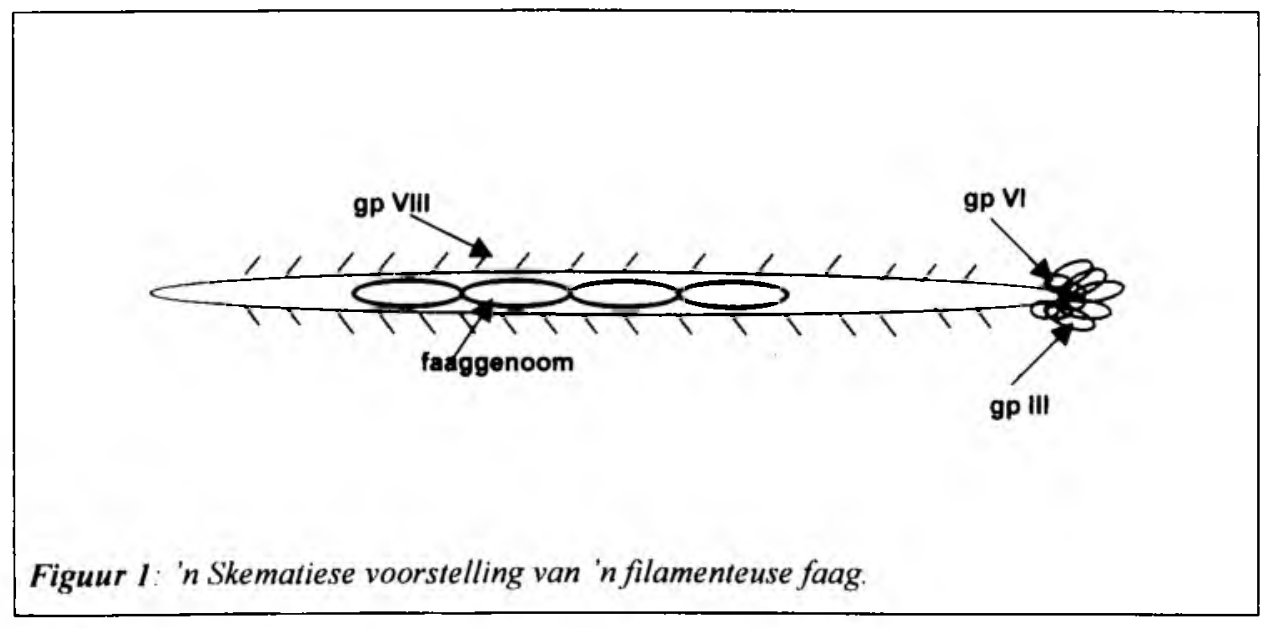




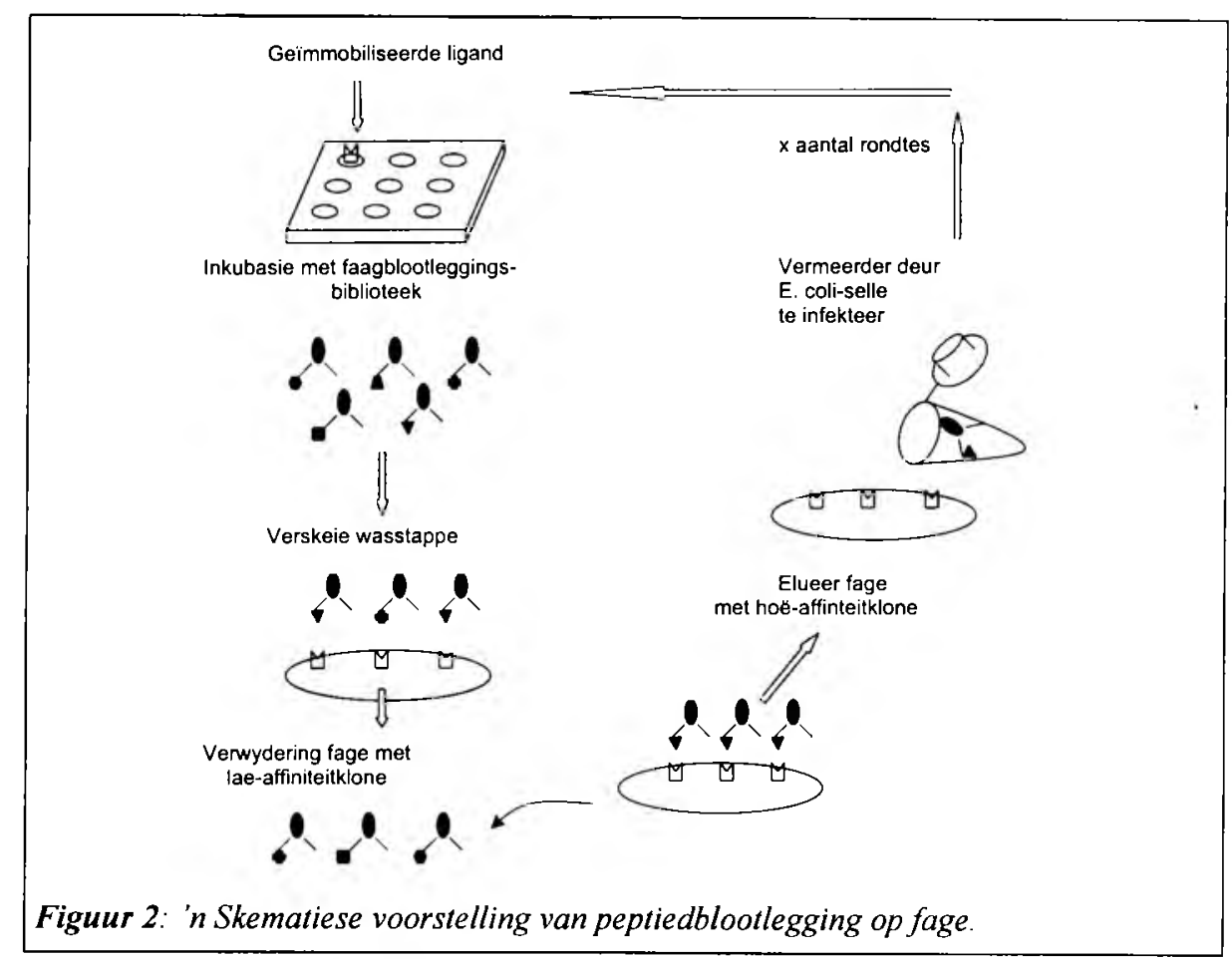

van die seleksieproses word bepaal deur 'n klein hoeveelheid van die geînfekteerde bakterieë wat na die laaste seleksierondte versamel is, op agarplate uit te plaat sodat enkelkolonies kan opgroei. Omdat 'n faag slegs een bakterie kan infekteer, sal elke kolonie ' $n$ versameling van identiese fage wees. Enkelkolonies wat opgetel en in mikrotiterplaatputte gekweek word, produseer dus monoklonale fage wat, na 'n sentrifugeringstap, versamel word. Hierdie fage word m.b.v. 'n ensiemgekoppelde immuunbepaling (ELISA)-tegniek getoets vir binding aan die teikenproteïen. Kortliks kom dit daarop neer dat die fage oorgedra word na mikrotiterputte waaraan die teikenproteïen gekoppel is. $\mathrm{Na}$ inkubasie word die nie-bindende fage afgewas en ' $\mathrm{n}$ antifaagantiliggaam, gekonjugeer aan peperwortelperoksidase (HRPO), in die putte gevoeg. $\mathrm{Na}$ ' $\mathrm{n}$ verdere wasstap word 'n kleursubstraat bygevoeg om die bindende faagkolonies te identifiseer.

\section{Volgordebepaling}

Die $E$. coli-kolonies wat bindende fage bevat, word gekweek om genoegsame hoeveelhede fage te produseer sodat die faag-DNA geïsoleer kan word. Die DNA-volgorde van die oligonukleotiedinvoeging word dan m.b.v. klassieke volgordebepalingstegnieke bepaal.

\section{DIE GEBRUIK VAN PEPTIEDBLOOTLEGGING IN TROMBOSE EN HEMOSTASE}

Navorsers op die gebied van trombose en hemostase maak reeds van peptied-, antiliggaam-, cDNA- en proteïenbiblioteke gebruik, enersyds om kandidate te identifiseer wat as antitrombotiese middels ontwikkel kan word, en andersyds om struktuurfunksie-verwantskappe in trombose te bepaal. Wat hierna volg, is slegs ' $n$ kort bespreking van die gebruik van hierdie biblioteke en die inligting wat daaruit verkry is.

\section{Peptiedbiblioteke}

Peptiede wat $7,10,15$ of 38 lukraakgekose aminosure as liniêre peptiede op die oppervlak van filamenteuse fage blootlê, word algemeen gebruik. 'n Variasie hiervan is om 'n sisteïen aan elk van die amino- en karboksieterminale van die peptiede in te bou sodat 'n sikliese peptied blootgelê word. ${ }^{7}$ Daar word algemeen aanvaar dat die bindingseienskappe van 'n sikliese peptied beter is as dié van 'n liniêre peptied. ${ }^{\text {? }}$

Die Arg-Gly-Asp-volgorde wat in die klewingsproteïene, fibrinogeen en fibrien voorkom, bind aan die GP IIb/IIIa-reseptor op die plaatjiemembraan en vorm sodoende 'n brug wat plaatjieaggregasie tot gevolg het. ${ }^{8}$ 'n Peptiedbiblioteek waar 'n Arg-GlyAsp-volgorde tussen twee stelle lukraak tripeptiede ingebou is, is gebruik om 'n effektiewe inhibeerder van plaatjie-aggregasie te isoleer.' Dit is gedoen deur die GP IIb/IIla-reseptor aan die wand van ' $n$ immuunbuis te immobiliseer en met die faagbiblioteek te inkubeer. Peptiede wat aan GP IIb/IIla bind, is geselekteer en getoets vir inhibisie van plaatjie-aggregasie.

Daar is verskeie groepe wat peptiedbiblioteke gebruik het om die epitoop waarmee monoklonale antiliggame aan hulle teikenprotelene bind, te bepaal. So byvoorbeeld is die epitoop van 'n menslike antiliggaam teen plasminogeenaktiveerder-inhibeerder tipe 1 en $\alpha_{2}$-makroglobulien bepaal. ${ }^{10}$ In die laasgenoemde geval is daar ' $n$ stel van vyf oorvleuelende fragmente wat oor 54 aminosure strek (van $\mathrm{Gly}_{4291}$ tot $\mathrm{Cys}_{4,344}$ ) van die $\beta$-ketting van die reseptor, geïsoleer.

Die trombienreseptor op die bloedplaatjiemembraan is ' $n$ integrale membraanproteïen. Trombien bind daaraan en sny sewe aminosure van die C-terminaal af. Die sewe-aminosuurligand wat vorm, is dan in staat om as ' $n$ trombienreseptor-agonis op te tree en die plaatjies via die reseptor te aktiveer. Hierdie eienskap van die reseptor is gebruik om 'n inhibeerder van die reseptor te isoleer." 'n Faagbiblioteek is gemaak met peptiede wat gegrond is op die peptiedvolgorde van die ligand. Hierdie biblioteek is met plaatjies geïnkubeer en die bindende fage m.b.v. die trombienreseptor-agonis geëlueer (figuur 3). Fage wat dus aan die trombienreseptor bind, is geëlueer en getoets vir inhibisie van die trombienreseptor. Die aminosuurvolgorde van die blootgelegde inhiberende peptiede is daarna bepaal en peptiede met dié 


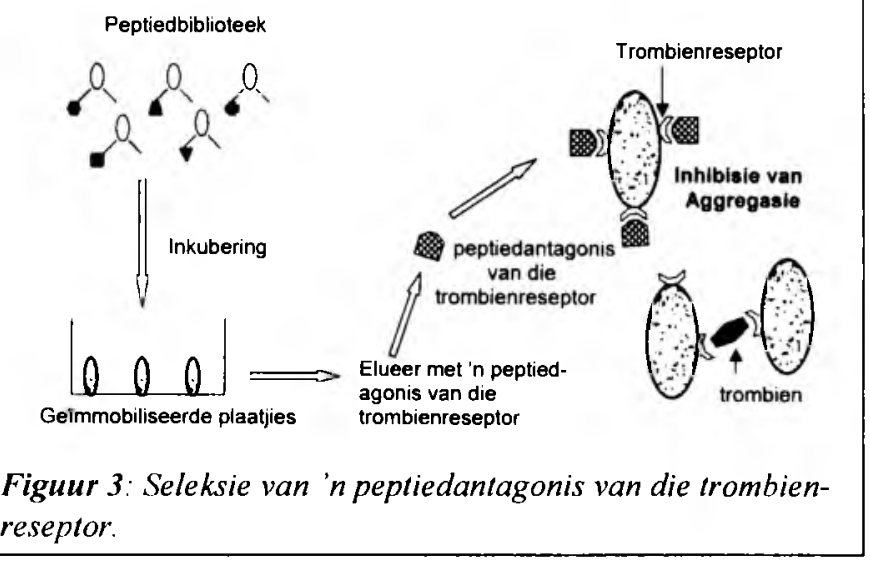

aminosuurvolgordes is gemaak.

Urokinase-tipe plasminogeen-aktiveerder (UPA) aktiveer fibrinoliese deur plasminogeen na plasmien om te skakel. Sy reseptor op bloedselle, die urokinasereseptor, reguleer die fibrinolitiese sisteem en bemiddel onder meer die metastasesering en indringing van tumorselle. 'n Nuwe teiken vir die terapeutiese behandeling van tumore is dus om die binding van uPA aan sy reseptor te blokkeer. ${ }^{12}$ Deur gebruik te mak van 'n 15-aminosuur lukraak peptiedbiblioteek, is twee peptiede wat sterk aan die urokinasereseptor bind, geïsoleer. Dit was interessant dat nie een van die twee peptiede se aminosuurvolgordes ooreengestem het met die bindingsetels van uPA aan die reseptor nie. In hierdie geval is daar dus twee peptiedligande van sel-oppervlakreseptore geïdentifiseer wat kan lei tot die ontwikkeling van inhibeerders van die reseptor. ${ }^{12}$

Plaaslik het ons 'n lukraak sikliese heptapeptiedbiblioteek gebruik om heptapeptiede wat aan $\alpha$-trombien bind, te isoleer. Hierdie peptiede herken spesifiek $\alpha$-trombien, maar inhibeer nie die funksie daarvan nie wat daarop dui dat hierdie peptiede aan 'n epitoop bind wat nie die proteolitiese aktiwiteit van trombien beïnvloed nie. Hierdie tipe peptiede kan aan radioaktiewe jodium gebind word en kan moontlik gebruik word om in vivotrombusvorming m.b.v. sintillasiekamera-tegnieke op te spoor. ${ }^{13}$ Trombien word in 'n trombus vasgevang ${ }^{14}$ en hierdie peptiede kan dan spesifiek aan trombien in die trombus bind waar dit m.b.v. 'n sintillasiekamera opgespoor kan word.

\section{Antiliggaambiblioteke}

In hierdie geval word antiliggame of gedeeltes daarvan op die oppervlak van fage blootgelê. Die doel is om veral mensantiliggame te kloneer wat dan as geneesmiddels ontwikkel kan word of in navorsing gebruik kan word. Soortgelyk aan die B-sel van die immuunstelsel wat antiliggaamgene bevat, en hulle op sy oppervlak blootstel, word antiliggaambiblioteke so gemaak dat mens-antiliggame of gedeeltes daarvan op die oppervlak van fage blootgestel word. Daardie fage wat aan die antigeen bind, word dan geselekteer.

Met behulp van antiliggaambiblioteke $\operatorname{kan} \mathrm{F}_{\mathrm{ab}}$-fragmente teen komplekse, biologiese antigene geïsoleer word. In 'n poging om antiliggame teen plasmingeen-aktiveerder-inhibeerder-tipe 1 te selekteer, het Lang et al. ${ }^{31}$ soos volg te werk gegaan: Hulle het 'n konyn met die $\alpha$-granule van mens-plaatjies geïmmuniseer en daarna die totale RNA uit die milt en beenmurg van die konyne ge-ekstraheer. Die RNA wat vir die $\kappa$-ligte en $\gamma$-swaarkettings kodeer, is geïsoleer, na cDNA getranskribeer, en in 'n faagmied ingebou om 'n $F_{a b}$-biblioteek te maak. Ses-en-veertig faagklone wat aan PAl-l bind, is m.b.v. hierdie biblioteek geîsoleer.

Hierdie antiliggaamfragmente op die fage kan weer van die mantelproteïen vrygestel word. ${ }^{15}$ Eerstens kan 'n stopkodon tussen die geen wat kodeer vir die antiliggaamfragment en dié vir die faag-mantelproteien ingebou word. Wanneer die stopkodon onderdruk word, bly die antiliggaamfragmente aan die mantelproteïen gebind, so nie, word dit vrygestel. ${ }^{15}$ Tweedens kan die geen wat kodeer vir die antiliggaamfragment m.b.v. 'n restriksie-ensiem van die mantelproteïengeen gesny word en in 'n ander vektor wat geskik is vir die sekresie van die antiliggaamfragmente, herkloneer word. ${ }^{16}$

\section{cDNA-biblioteke}

Die cDNA-biblioteke vind al hoe meer toepassing in tromboseen hemostase-navorsing. Die totale mRNA van 'n sel, orgaan of organisme word voorberei, getrutranskribeer na cDNA en in die faaggeen van GP III of IV ingebou. In die laasgenoemde geval word die vreemde proteïen aan die karboksie-terminale kant van GP VI geheg. Dit is ook die mees praktiese manier om die uitdrukking van 'n cDNA-biblioteek te verseker, aangesien die vreemde cDNA met hulle 5'-kante aan die faag-DNA heg. Die voordeel is dat die $5^{\prime}$-kant nie ribosoombindingsetels het nie en dat daar alreeds translasionele stopseine aan die $3 '-k$ ant is. Dit beteken dat die stoppe nie die blootlegging van die vreemde proteïen op die mantelproteïen kan beïnvloed nie. ${ }^{17}$ 'n Voorbeeld hiervan is 'n cDNA-biblioteek wat gemak is van die haakwurm Ancylostoma caninum. Hierdie biblioteek is in pDONG6-faagmiedvektore gekloneer en fage wat aan tripsien of faktor Xa bind, is geselekteer. ' $n$ Nuwe tripsieninhibeerder, struktureel verwant aan die Kunitz-tipe serumprotease-inhibeerders, en 'n faktor Xa-inhibeerder is uit hierdie biblioteek geïsoleer. ${ }^{18}$

\section{Proteïenbiblioteke}

In die geval van proteïenbiblioteke word 'n hele proteïen op die oppervlak van die filamenteuse faag blootgelê. Hierdie proteïene kan varieer van klein proteïene soos groeihormoon ${ }^{19}$ en pankreas-tripsieninhibeerder ${ }^{20}$ tot groter proteïene soos alkaliese fosfatase $^{21}$ en $\alpha$-laktamase. ${ }^{22}$ Proteïen-struktuurfunksiestudies vind baie hierby baat, veral nadat verskeie groepe al aangetoon het dat 'n groot verskeidenheid proteiene op filamenteuse fage blootgelê kan word sonder 'n verlies aan funksionele aktiwiteit. ${ }^{19-22}$ Die tegniek het tot gevolg dat 'n groot aantal mutante proteïene gegenereer kan word en verskaf 'n goeie seleksiestrategie om mutante met die gewenste fenotipe te identifiseer. In die geval van groeihormoon byvoorbeeld, het die seleksie op geïmmobiliseerde reseptore gelei tot die identifikasie van mutante met 'n hoër affiniteit vir sy reseptor as in die geval van die oorspronklike proteïen. ${ }^{19}$

In trombose en hemostase is ensieme soos PAI-1 op fage blootgelê. PAI-1 wat op fage blootgelê word, behou sy vermoë om tPA te inhibeer. ${ }^{23}$ ' $n$ Biblioteek van PAI- 1 -mutante is gebruik om te bepaal watter aminosuurvolgorde van PAI-I aan trombien bind. ${ }^{23}$

Jespers et al. ${ }^{24}$ het 'n biblioteek van lukraak variante van staphilokinase (SAK) gemaak en op dié wyse die epitope van 2 monoklonale antiliggame teen staphilokinase (SAK) bepaal. Hierdie variante bevat enkel, dubbel of trippel aminosuurmutante. Die werkswyse was om die biblioteek negatief te 
selekteer vir SAK-variante wat nie aan die monoklonale antiliggame bind nie. Uit hierdie geselekteerde fage is dan variante geselekteer wat aan plasmien bind. Na verskeie seleksierondtes, is die aminosuurvolgorde van die geselekteerde fage bepaal. Die aminosuurvolgorde van daardie mutante wat die hoogste voorkoms het, weerspieël dan die funksionele epitoop van die antiliggaam.

\section{SAMEVATTING}

Hierdie oorsig bespreek die tegnieke van peptied- en proteïenblootlegging op fage, asook variasies daarvan. Toepassings op die gebied van trombose en hemostase word ook gegee. Daar moet egter besef word dat hierdie tegniek ook baie ander toepassings buite die veld van trombose en hemostase het. So byvoorbeeld word die tegniek gebruik om geneesmiddels en gene in geselekteerde weefsels te plaas deur peptiede te selekteer wat vaskulêre selmerkers identifiseer. ${ }^{25}$ Dit word ook gebruik in die ontwikkeling van entstowwe. ${ }^{26}$ Alhoewel hierdie tegniek nog relatief nuut is, het dit al baie bygedra tot die uitbouing van ons kennis van veral struktuurfunksie-verwantskappe van ensiemreaksies, inhibisie van in vivo-prosesse en die ontwikkeling van geneesmiddels. ${ }^{6.18 .27}$ Dit is baie bemoedigend om waar te neem dat hierdie tegnologie alreeds ' $n$ hoofrol in die gebied van trombose en hemostase begin speel. Daar word verwag dat, soos hierdie tegnieke meer toegepas word, 'n verdere kennisontploffing in die gebied sal plaasvind.

\section{SUMMARY}

\section{INTRODUCTION}

Haemostasis is a protective mechanism that limits excessive blood loss. Thrombosis, on the other hand, is the antitype of haemostasis. Following blood vessel injury, when the blood comes into contact with the sub-endothelium, the blood platelets adhere to sub-endothelial structures and become activated. Simultaneous activation of the coagulation factors form thrombin. In concert, platelets and thrombin form a platelet plug to prevent excessive blood loss. Endothelial cells in the vicinity of the platelet plug secrete prostacyclin, nitrogen-oxide and fibrinolytic agents that limit the size of the plug. Excessive activation of platelets by atherosclerotic lesions overcome these thromboregulatory mechanisms and the platelets and coagulation factors then become thrombotic offenders that occlude the blood vessel at the site of injury or form thrombo-emboli that can block blood vessels distal to the site of injury. In view of this, more effective anti-thombotic agents are being investigated. For this purpose, phage display technology is ideally suited because it is a powerful and rapid method to isolate or design proteins with specific anti-thrombotic functions.

\section{PHAGE DISPLAY}

Phage display is a technique that expresses or "displays" a peptide or protein on the surface of a filamentous phage. This is accomplished by the insertion of a gene or gene fragment in a phage surface protein gene. The insert will result in a fusion peptide/protein on the phage surface, provided that the reading frame is correct and that the insert does not interfere with the essential functions of the surface protein. If the peptide is well exposed on the surface it will be available to act as a ligand, enzyme, and immunogen or otherwise actively participate in a biochemical process. The insertion of random oligonucleotide sequences provides a means of constructing extensive peptide libraries that may be screened to select peptides with specific affinities or activities. The separation of phage particles expressing different peptide inserts on the phage surface protein is accomplished by affinity selection.

\section{THE USE OF PHAGE DISPLAY IN THROMBOSIS AND HAEMOSTASIS}

Scientists already use peptide, antibody, cDNA and protein phage libraries to identify and develop effective antithrombotics.

Peptide libraries were used to select peptides that bind to and inhibit the glycoprotein IIb/IIla-receptor on platelets and an inhibitor of the thrombin receptor on platelets was also isolated. Both these peptides inhibit platelet aggregation. A peptide that inhibits the urokinase receptor that may have anti-tumor activities was also selected. We selected thrombin-binding peptides that can be used to detect in vivo thrombus formation with a scintillation camera.

Antibody libraries are formed by displaying antibodies or parts of antibodies on filamentous phages. In this way, antibodies to the plasminogen activator inhibitor-type 1 (PAI-I) were selected from a mixture of antibodies.

In the case of cDNA libraries, the total mRNA of a cell, organ or organism is collected and reverse transcribed to cDNA. The cDNA is then inserted into the phage genome to display foreign proteins on the phage surface. An example is a cDNA library made from the hookworm Ancylostoma caninum. Inhibitors of trypsin and factor $\mathrm{X}_{\mathrm{a}}$ were selected form this library.

Protein libraries were made where enzymes, such as PAI-I, was displayed on the surface of phages. A library of PAI-1 mutants was then used to determine which sequence in PAI-1 binds to thrombin. The functional epitope of two monoclonal antibodies to staphylokinase were also determined by using a library of random variants of SAK

Although the technique of phage display is relatively new, its use has already made remarkable contributions in the field of thrombosis and haemostasis. It is not only suitable to select specific binders to proteins but also expand our knowledge of structure function relationships and to develop effective agents for treatment. We expect that the increasing use of phage display will result in an explosion of our knowledge of the mechanisms involved in thrombosis.

\section{LITERATUURVERWYSINGS}

1. Marcus, A.J., Safier, L.B. (1993). Thromboregulation: multicellular modulation of platelet reactivity in hemostasis and thrombosis. FASEB Journal, 7, $512-522$.

2. Gimbrone, M.A. (1986). Vascular endothelium: Nature's blood container In: Gimbrone, M.A. (ed). I'ascular endorhelitum in haemostasis and thrombosis (Churchill Livingstone. New York). pp. I-9.

3. Gimbrone, M.A. (1986). Vascular endothelium: Nature's blood container In: Gimbrone. M.A. (ed). Vascular endothetium in haemostasis and thrombosis (Churchill Livingstone, New York). pp. I-9

4. Smith, G.P. (1985). Filamentous fusion phage: novel expression vectors that display cloned antigens on the surface of the viron, Science, 228. 1315-1317.

5. Baas, P.D. (1985). DNA replication of single-stranded Escherichia coli DNA phages, Biochim. Biophys. Acta. 825.111-139.

6. Doorbar, J., Winter. J.A. (1994). Isolation of a peptide antagonist to the thrombin receptor using phage display. J Mol. Biol., 244, 36l-369

7. Scott, J.K., Smith, G.P. (1990). Searching for peptide ligands with an epitope library, Science 249, 386-390.

8. Philips, D.R., Charo. I.F., Parise, L.V.. Fitzgerald, LA. (1988), The platelet membrane glycoprotein IIb/IIIa complex. Blood, 71, 831-834

9. Ke, S-H., Coombs, G.S., Tachias. K.. Navre, M., Corey, D. R., Madison, E.L. (1997). Distinguishing the specificities of closely related proteases, J. Biol. Chem., 272, 16603-16609 
10. Van Zonneveld, A-J., van den Berg, B.M.M., van Meijer, M., Pannekoek, II. (1995). Identitication of functional interactions sites on proteins using bacteriophage-displayed random epitope libraries, Gene, 78, 1097-1103.

11. Vu T-K.Il, Hung, D.T., Wheaton, V.I., Coughlin, S.K., (1991). Molecular cloning of a functional thrombin receptor reveals a novel proteolytic mechanism of receptor activation, Cell, 64, 361-369.

12. Goodson, R.J., Doyle, M.V., Kaufman, S.E., Rosenberg, S. (1994). Highaffinity urokinase receptor antagonists identified with bacteriophage peptide display, Proc. Natl. Acad. Sci. USA, 91, 7129-7133.

13. Kotze, H.F., Badenhorst, P.N., Lamprecht, S., Meiring, S.M., Van Wyk, V., Nuyts, K., Stassen, J.M., Vermylen, J., Deckmyn, 11. (1995). Prolonged inhibition of acute arterial thrombosis by high dosing of a monochlonal antiplatelet glycoprotein lib/IIla antibody in a baboon model, Thromb. Haemost., 74(2), 751-757

14. Stubbs, M.T., Bode, W. (1993). A player in many parts: the spotlight on thrombin's structure, Thromb. Res, 69, 1-58.

15. Hoogenboom, H.R., Griffiths, A.D., Johnson, K.S., Chriswell, D.J., Hudson, P., Winter, G. (1991). Multi-subunit proteins on the surface of filantous phage methodologies for displaying antibody (Fab) heavy and light chains, Nucleic Acids Res, 19, 4133-4137.

16. Barbas III, C.F., l.erner, R.A. (1991). Combinatorial immunoglobulin libraries on the surface of phage: rapid selection of antigen-specific Fabs, Methods, 2, 119-124.

17. Subbs. M.T., Bode, W. (1993). A player in many parts: the spotlight on thrombin's structure, Thromb. Res, 69, 1-58.

18. Gramatikoff, K., Georgiev, O., Schaffner, W. (1994). Direct interaction rescue. a novel filamentous phage technique to study protein-protein interactions. Nucleic. Acids., 22, 5761-5762
19. Bass, S., Greene, R. Wells, J.A. (1990). Iformone phage: an enreichment metluod for variant proteins with altered binding properties. Proteins. 8. 309-314.

20. Markland, W., Roberts, B.L., Saxona, M.I. (iutterman, S.K.. Ladner, R.C (1991). Design, construction and tunction of a multicopy display vector using fusions to the major coat protein of bacteriophage. Gene, 109. 13-19

21. McCafferty, J., Hackson. R.H., ('hriswell. I) J. (|991) Phage-enzymes expression and aftunity chromatography of functional alkaline phosphatase on the surface of bacteriophage. Prot. Eng.. 48. 955-96I

22. Soumillion, P., Jespers, L., Bouchet, M.. Marchand-Brynaert, J., Winter, G, Fastrez, J. (1994). Selection of ( $x$-lactamase on filamentous bacteiophage by catalytic activity. .J. Mol. Biol., 237, 415-422.

23. Pannekoek, H., van Meijer. M. Scleet. R., Loskutoff, D.J., Barbas III, C.F. (1993). Functional display of human plasminogen-activator inhibitor (PAI-I) on phages: novel perspectives for sturcture-function analysis by error-prone DNA synthesis. Gene. 128, 135-140.

24. Jespers, L.. Jenne, S., Lasters. I. (ollen. I). (1997). Epitope mapping by negative selection of randomized antigen libraries displayed on filamentous phage, J.Mol. Biol., 269, 704-718.

25. Barry, M.A., Dower. W.J., Jolunson. S.A. (1996). Toward cell-targeting gene therapy vectors: selection of cell-binding peptides from random peptide-presenting plage libraries. Nature Med. 2, 299-305.

26. Barbas III, C.F.. Burton, D. R. (1996) Selection and evolution of highaffinity human anti-viral antibodies. Tiblech. 14, 230-234

27. Katz, B.A. (1997). Structural and mechanistic determinations of aftinity and specificity of ligands discovered or engineerd by phage display, Anmu. Rev. Biophys. Biomol. Siruct, 26, 27-45

Muriel Meiring is Eerste Mediese Natmurwetenskaplike in die Departement Hematologie en Selbiologie aan die Universiteit van die Oranje-Vrystaat. Sy het haar B.Sc.-graad en B.Sc.Honneursgraad in Fisiologie aan die Potchefstroomse Universiteit vir Christelike Hoer Onderwys behaal. Sy het 'n M.Med.Sc.-graad met lof en 'n Ph.D.-graad, albei in Hematologie, aan die (Iniversiteit van die ()ranje-Vrystaat behaal. In 1997 het sy in beurs van die lilaamse (iemeenskap ontvang om haar postdoktorale studie in Belgie te doen. Sy is onteur en mede-outeur van vyf joernaalartikels 